ues, "[T] he issue is not how to get wide participation in early warning. The real issue is how to get broader participation in global-scale decision-making." Perhaps the proposed academic policy consortium could contemplate encouraging participation of this nature as a principal task?

These are the issues. We can debate their relative merits, but, in the end, we come back to the key issues. Should we invest in early warning? If yes, who is responsible, where and how should it be done? And, can we develop an effective and useful early warning system? If yes, how and to what end? Whatever steps are taken, lessons learned from past and recent humanitarian crises must and should form the background and foreground for the focus of international action and individual endeavour.

\section{Notes}

1. This is discussed by GavanDuffy, Ted Robert Gurr, Philip A. Schrodt, Gottfried Mayer-Kress and Peter Brecke in "An Early Warning System for the United Nations: Internet or Not?" in the "The Forum," Mershon International Studies Review, Vol. 39, Supplement 2, October 1995, 315-26.

2. See "ReliefWeb: Mandate and Objectives" in this issue.

3. See "Towards the Development of an Early Warning/Response Network" in this issue.

\section{References}

Adelman, Howard, and Astri Suhrke. 1996. "Early Warning and Conflict Management." Study 2, Joint Evaluation of Emergency Assistance to Rwanda. Toronto: York University.

Brecke, Peter. 1995. "What Stirs Concern Is What Might Need to Be Done." Mershon International Studies Review, Vol. 39, Supplement 2, October 1995, 321-23.

Deqni-Sequi, R. 1994. Special Rapporteur's Report on the Situation of Human Rights in Rwanda. UNCommission on Human Rights.

Mershon International Studies Review. 1995. "The Forum," No. 39, 315-26.

Millwood, David (ed). 1995. The International Response to Conflict and Genocide: Lessons Learned from the Rwanda Experience. Early Warning and Conflict Management Steering Committee of the Joint Evaluation of Emergency Assistance to Rwanda. Odense: Standberg Grafisk. \

\title{
Early Warning and Conflict Prevention
}

\author{
Andrew Cottey
}

\section{Résumé}

\section{Ce bref article porte un regard critique} sur les mécanismes d'alerte préventive en place actuellement et évoque des enjeux similaires à ceux soulevés par l'article de Sharon Rusu. L'auteur tente ici de décrire la nature et le fonctionnement $d u$ système existant, les acteurs qui $y$ sont engagés ainsi les imperfections et lacunes de processus dans son état actuel.

Increasingly, large-scale refugee movements and other humanitarian disasters (famine, environmental crises, economic collapse, the breakdown of state structures) are caused by wars, especially civil wars, and prolonged internal conflicts. If humanity is to avert such disasters, we need to develop new means of conflict prevention. This in turn depends, in part, on developing effective mechanisms to provide early warning of potential conflicts.

Since the end of the Cold War, policy-makers and governments have accepted the need to develop new means of conflict prevention. In $A n$ Agenda for Peace, United Nations (UN) Secretary-General Boutros BoutrosGhali highlighted the importance and potential of various forms of 'preventive diplomacy.' The Clinton administration views conflict prevention as a central element of the United States' post-Cold War foreign policy. Many other governments are sympathetic to the idea. Regional bodies such as the Organization for Security and Cooperation in Europe (OSCE) and the Organization of African Unity (OAU) now see conflict prevention as one of their key roles.

Putting conflict prevention into practice, however, is more difficult.

Andrew Cottey, Department of Peace Studies, University of Bradford, U.K.
The development of effective mechanisms for early warning of potential violent conflicts is inherently problematic. Political instability, economic decline, disputes over borders or ethnic minorities, mobilization of peoples and increased arms flows may be signs of impending conflicts. However, many, perhaps even most, countries are characterized by some of these features. Determining which particular regions and countries are most likely to escalate to warfare-and therefore require urgent attention-is far more difficult. Although the UN and regional organizations are beginning to develop mechanisms to provide early warning of impending conflicts, how far these mechanisms can be truly effective is not yet clear.

Even if effective early warning mechanisms are established, they will be of little use if warnings are ignored or side-lined. Internal UN reports, for example, warned of plans for the genocide that was to occur in Rwanda in 1994, but were suppressed because they were politically inconvenient for some governments. Many observers warned from Tito's death in 1980 onwards of the potential for conflict in the former Yugoslavia, and the U.S. Central Intelligence Agency specifically warned in 1990 of impending conflict.

Further, even where the political will to take action exists, developing effective policies is difficult. Neutral mediation and conflict resolution efforts may be effective in some circumstances. In many conflict situations, however, positions are deeply entrenched or the parties involved have an active interest in perpetuating the conflict. In these circumstances, 'rational' diplomatic persuasion and 'good offices' are unlikely to resolve real differences. Bringing pressure to bear on parties to a conflict, however, is difficult and poses its own dilem-

Refuge, Vol. 15, No. 4 (1996) 
mas. Economic sanctions are a blunt instrument, whose record of success is dubious. Some analysts argue that preventive military intervention may sometimes be the only realistic option. But this also raises obvious risks and dangers.

An underlying problem is the disjuncture between states commitments to the idea of conflict prevention and the resources they are willing to invest and the risks they are willing to take to prevent conflicts. Many observers argue that had the major Western powers been willing to deploy a substantial preventive force in Bosnia in late 1991 or early 1992 the subsequent conflict might have been avoided. Similarly, some suggest that had the UN presence in Rwanda been increased when violence escalated in the spring of 1994 much bloodshed could have been averted. Instead, the UN Security Council, wary of the risks of deeper involvement, chose to reduce the UN peacekeeping force in that country. Whether those states with the power to take more effective action have the will or the interest to do so is therefore open to doubt.

Some Third World states also fear that early warning and conflict prevention could become an excuse for growing Western interference in their internal affairs. With most conflicts occurring within states, early warning and action to tackle conflicts inevitably implies increased monitoring, of and intervention in, the domestic politics of states where conflict may be likely. Such fears have led some Third World states to oppose the setting up of an inter-agency early warning mechanism within the UN, stalling progress in this area. More broadly, there is a risk that Western-led efforts to develop early warning and conflict prevention mechanisms could come to be seen as part of a new 'neo-imperialism,' contributing to the growing polarization of North-South relations.

If these various problems are to be overcome, there is a need to develop approaches which are less dependent on the short-term attention and narrow interests of particular states and governments. Strengthened international organizations, whose action does not always depend on the active support of governments, are one way forward. Within the UN, the Department of Political Affairs was set up by Boutros-Ghali specifically to support conflict prevention and resolution. Its confidential mediation efforts have probably helped to prevent a number of latent conflicts from escalating to violence. Within Europe, the OSCE's High Commissioner on National Minorities has helped to promote dialogue in a number of potential ethnic conflicts and is widely regarded as an important success story for conflict prevention.

Another approach is to support the development of non-governmental groups involved in grassroots conflict resolution and peace-building efforts. Some analysts, disillusioned with the failure of more traditional state-centric and government oriented approaches, suggest that this may be a key area for development. Bodies like the European Union, for instance, could provide far greater financial support for non-governmental conflict prevention and resolution efforts in Eastern Europe, the former Soviet Union and Africa.

Conflict early warning and prevention face very real problems. We are, however, at a relatively early stage in their post-Cold War development. The UN Department of Political Affairs and the OSCE High Commissioner on National Minorities provide an indication of the potential for success. If we are to make further progress, there is a need for a wide range of new and imaginative approaches. The conflict prevention agenda, further, needs to be broadened to address the underlying causes of conflict in many parts of the world (poverty, the lack of democracy and respect for human rights, environmental degradation, arms proliferation).

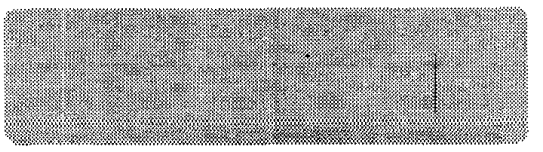

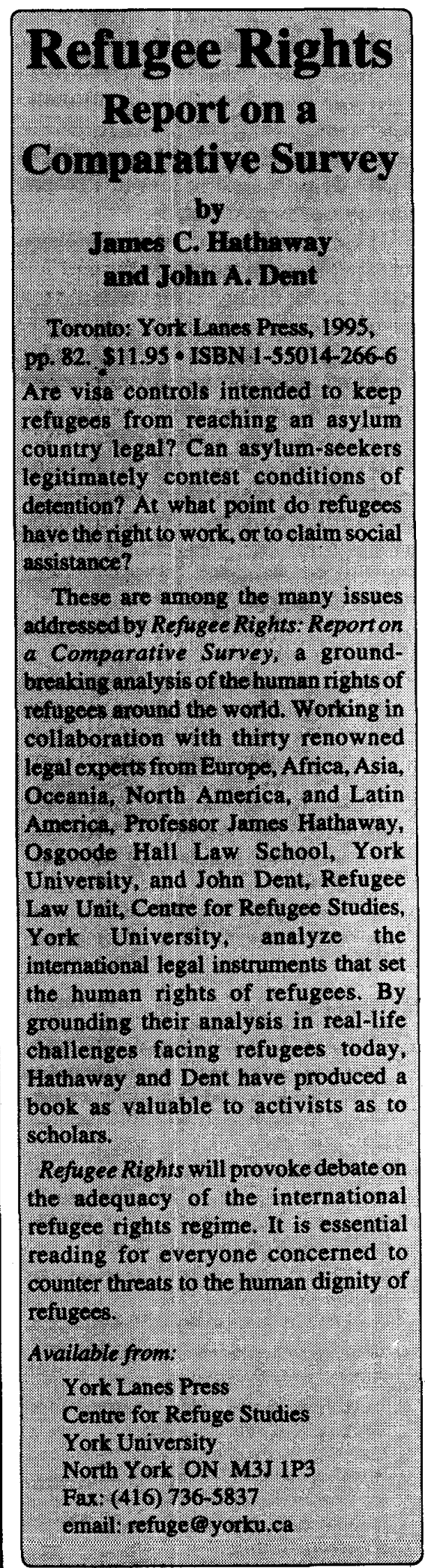

